\title{
Poezja nagrobków
}

Andrzej Borowski 


\section{UAPIS Seria III 1997}

\section{Poezja nagrobków}

Poezja - widzimy to ostrzej chyba aniżeli kiedykolwiek — zdaje się być szczególnie bezradna wobec śmierci. Dawniej określało się dosadniej jeszcze: wobec „majestatu śmierci”, czy mówiąc ogólniej: „majestatu” cierpienia — co być może lepiej oddawało przepaść dzielącą sumę doświadczeń życiowych od rozpościerającej się poza granicą życia organicznego i poza wiedzą o przyczynach zła, tajemnicy. Owa dowiedziona w naszym stuleciu wielokrotnie bezradność poezji w obliczu cierpienia i śmierci unaocznia zarazem daremność oczekiwań tych wszystkich, którzy od sztuki, zwłaszcza zaś od poezji, spodziewaliby się jakiejkolwiek skutecznej pociechy. A przecież są ludzie, którzy od poetów oczekują znacznie więcej, bo oczekują nadziei. Pocieszenie człowieka w sytuacji granicznej i danie mu nadziei sięgającej poza jakiekolwiek granice to sprawa religii. Sprawą poety natomiast jest opis, jest studium człowieczeństwa przejętego zarówno rozpaczą, jak i nadzieją. Sprawą poezji jest również swoisty dla danej kultury opis człowieczego losu. Dlatego wbrew pozorom śmierć, zwłaszcza zaś ów jej „majestat” czyli misterium tremendum to wcale nie jest po prostu i naturalnie, jak się niektórym może wydawać, temat poetycki. Z zadumy nad śmiercią i nad przemijaniem wyrasta filzofia, zaś poezja poprzestaje zazwyczaj na bardzo swoistym, właściwym dla języka poetyckiego i w gruncie rzeczy skromnym, powściągliwym, a przez to jakże wymownym i przejmującym komentarzu.

Od poezji oczekiwano kiedyś upamiętnienia. Mówiono nawet — „unieśmiertelnienia”, co dzisiaj trudno jakoś napisać bez cudzysłowu. Cóż dopiero pomyśleć! Cmentarze wierszów są przecież równie rozległe i nie mniej przygnębiające, jak cmentarze ludzi i pochowanych wraz z ludźmi autorytetów. Zaś horacjańskie non omnis moriar robi na ludziach dnia powszedniego wrażenie niezrozumiałego, nieczytelnego epitafium. Zaś wspomniany w tej samej odzie „pomnik trwalszy od spiżu” to zarazem przygnębiający, gdy rozejrzeć się trzeźwo wokól siebie, nagrobek umarłego dla naszej cywilizacji poety. Właściwie jest to także epitafium dla całej pogrzebanej pod warstwami gruzu kultury śródziemnomorskiej.

Topos „unieśmiertelnienia przez poezję” przemawiał jednak na tyle sugestywnie do ludzkiej uczuciowości, że twórczość nagrobkowa i epicedialna przeżyła najdłużej spośród wszystkich klasycznych gatunków poezji okolicznościowej. Ich kontynuacją są wypisywane na nagrobkach (osobno też na klepsydrach czy na zawiadomieniach o zgonie!) teksty o rozmaitej wartości artystycznej i emocjonalnej. Są to zarówno urywki znanych powszechnie 
utworów z „kanonu lektur” jak i twórczość samodzielna, często więc i nieporadna. Dlatego patrzymy na owe teksty raczej jak na ciekawostki, które zajmowały dotąd uwagę głównie badaczy folkloru. Nie ma natomiast poezji żałobnej w klasycznym rozumieniu tzn. $z$ dobitnym uwydatnieniem zasług zmarłej osoby, a także $z$ wyeksponowanym akcentem konsolacyjnym. Być może do ostatecznego zaniku takiego wzorca przyczyniło się i to, że w takim właśnie „pseudoklasycyzmie” lubowała się skompromitowana doszczętnie twórczość propagandowa w minionych epokach nowoczesnej tyranii. Natomiast tematyka śmierci jest wyraziście obecna zarówno w literaturze, jak w całej zresztą kulturze powszechniej. Więcej nawet - śmierć, do niedawna jeszcze upostaciowiona w ikonografii i w obrazowaniu literackim, więc do pewnego stopnia „zabezpieczona”, skonwencjonalizowana, zamknięta i ograniczona formami gatunków okolicznościowych, jest teraz jako temat, właściwie wszędzie i zawsze, od popularnej czy subkulturowej nawet twórczości artystycznej aż po dzieła najwznioślejsze i najbardziej dyskretne, najbliższe medytacji. Dlatego tak ważne jest, aby w tym stanie wszechobecności tematyki „tanatologicznej” w kulturze współczesnej umiano się zdobyć na dystans, na osąd, na refleksję wartościującą poszczególne wypowiedzi, dzieła sztuki, utwory literackie.

Coraz więcej też publikacji poświęconych umieraniu, cmentarzom, pomnikom nagrobnym, wreszcie też i samym tekstom nagrobkowym, które stanowią osobny i, jak się właśnie możemy przekonać, wciąż osobliwie żywotny gatunek literacki. Łatwo się domyślać kilku uzasadnień zainteresowania cmentarzem jako tematem badawczym. Nie ma już cenzury, która niedawno jeszcze bardzo skrupulatnie takim rozprawom, zwłaszcza zaś publikacjom popularnym się przyglądała, szukając w nich, nie bez racji, zagrożenia dla urzędowo sfingowanego obrazu narodowej przeszłości. Coraz mniejszą sensację wywołują wśród publiczności czytelniczej albumy ze zdjęciami polskich mogił, zwłaszcza żołnierskich w Wilnie czy we Lwowie. Także i wciąż odkrywcze publikacje na temat rozrzuconych po całym obszarze dawnego Związku Sowieckiego grobów polskich więźniów i zesłańców przyjmuje się jako naturalny składnik wiedzy o narodowej przeszłości.

Zainteresowanie się historyków literatury nagrobkami ma jednak jeszcze przyczynę głębsza, aniżeli przejściowa koniunktura czy historycznoniepodległościowe emocje. Sądzę, że można tu mówić o rewizji obowiązującego do niedawna jeszcze przesądu metodologicznego. Poezję okolicznościową, również epicedialną i epitafijną traktowano często ze szczególnym dystansem i oziębłością. Podejrzewana o panegiryzm i spychana na margines literatury artystycznej, niemalże aż do folkloru literackiego, nie wzbudzała refleksji na temat podstawowych kwestii moralnych. W najlepszym razie wydawała się „zabawna” jak poezje ks. Baki, które zabawnymi wcale nie są.

To, jak głęboką wartość, gdy idzie o poznanie wiedzy o człowieczeństwie zawartej w kulturze staropolskiej posiada owa poezja, udowodniła w swych znakomitych studiach Alina Nowicka-Jeżowa ${ }^{1}$. Autorka ukazała tam w sposób bardzo pouczający i inspirujący oddziały-

1 A. Nowicka-Jeżowa, Homo viator - mundus - mors. Studia $z$ dziejów eschatologii $w$ literaturze staropolskiej, cz. 1-3, Warszawa 1988. 
wanie topiki wanitatywnej, które wykracza daleko poza funkcje doraźnie tylko ascetyczne. W rzeczywistości miała bowiem owa topika wskazywać na cele transcendentne, na ostateczne zwycięstwo człowieka poddanego tymczascm doświadczeniu cierpienia, zmienności i rozkładu. W wymiarze eschatologicznym skupiała więc ostatecznic uwagę na życiu, nie na śmierci. W ten sposób Nowicka-Jeżowa przyczyniła się do rozbicia obiegowego i krzywdzącego wielce dla literatury staropolskiej (szczególnie barokowej) mniemania o jej rzekomym zapatrzeniu się w śmierć i w marność stworzenia.

Interesującą kontynuację tego kierunku analizy polskicj poezji barokowej stanowi książka Pawła Stępnia, który starał się „postawę wobec śmierci i przemijania określić na podstawie analizy utworów erotycznych"2. Jest to pozornie tylko niezwykłe, dla kogoś może nawet paradoksalne poszerzenie zainteresowań „literaturą o umieraniu”, bowiem artystyczna choćby (nie mówiąc już o eschatologii) bliskość miłości i śmicrci była dla poetów europejskich doby Renesansu i Barcku tematem szczególnic urzekającym.

Jeszcze inne zasługi mają badania nad barkowym epicedium polskim Macieja Włodarskiego ${ }^{3}$, który wcześniej zapoczątkował u nas studia nad ,tanatologią literacką" swoją pionierską książką o średniowiecznej „ars moriendi”, dodając niebawem do niej drugą jeszcze publikację, jakby uzupełniającą, choć zupełnie nowym kwestiom poświęconą ${ }^{4}$. Badania nad poezją funeralną w Polsce miały zresztą starsze i solidne fundamenty. Odkrywcza kiedyś i jedyna dotąd monografia Stefana Zabłockiego Polsko-tacińskie epicedium renesansowe na tle europejskim (1968) wskazywała wszystkim młodszym badaczom ogólny kierunek studiów. Podobnie inspirująco i pouczająco oddziaływały różnorodne pod względem ciężaru gatunkowego i szczegółowych zainteresowań ich autorów prace poświęcone naśladowcom i kontynuatorom Trenów Jana Kochanowskiego, z podstawową dla przedmiotu monografią Janusza Pelca. Dotyczyła ona wszelako całości oddziaływania poety czarnoleskiego na poetów staropolskich, zatem kształtowanie się siedemnastowiecznej poezji funeralnej pod wpływem poety czarnoleskiego omawiała na równi $z$ innymi zagadnieniami. Włodarski natomiast napisał swoją książkę o epicedium barokowym przyjmując na podstawę analizy kilku reprezentatywnych dla gatunku, jak też i dla prądu, tekstów. Można było oczywiście dodać, jak zawsze w takim przypadku, jeszcze kilka innych epicediów, lecz taka powiększona tylko pod względem ilościowym „próba” końcowych wniosków by nic zmieniła. Istotne bowiem dla monografii Włodarskiego było to, że autor polegał rozsądnie na analizic filologicznego opisu poprzedzającego ich interpretację. Określił w ten sposób paradygmat interpretacyjny nie

${ }^{2}$ P. Stępień, Poeta barokowy u’obec przemijania i śmierci. Hieronim Morsztyn, Szymon Zimorouric, Jan Andrzej Morsztyn, Warszawa 1996 (Res Humanae. Studia II). Przytaczam ze Stowa wstępnego na s. 5.

3. M. Włodarski, Barokowva poezja epicedialna. Analizy, Kraków 1993.

${ }^{4}$ M. Włodarski, Ars moriendi w literaturze polskiej XV i XVI w., Kraków 1987; tenże, Obraz i stowo. O pouriazaniach w sztuce i literaturze XV-XVI wieku na przykladzie „ars moriendi”, Kraków 1991. 
narzucony z zewnątrz, ale wyprowadzony niejako z samego wnętrza świata w epicediach tych przedstawianego. Dzięki przyjęciu tej zasady i dzięki zachowaniu wobec niej wierności książka Włodarskiego przejrzyście i czytelnie unaocznia główne topoi w epicedium barokowym wykorzystywane, a także bardziej złożone konstrukcje stylistyczne, które można w tym gatunku uznać za typowe. Dodatkowym osiągnięciem tej książki było po prostu poszerzenie i poprawienie naszej wiedzy na temat twórczości m.in. Daniela Naborowskiego czy Samuela Twardowskiego. Przy tej sposobności ujawniły się w sposób szczególnie wyrazisty jeszcze inne, nie znane dotąd związki w dziedzinie kompozycji i stylistyki pomiędzy mową okolicznościową a poezją funeralną. Najważniejszym jednak osiągnięciem Macieja Włodarskiego było pokazanie, choćby na przykładzie łacińskich i polskich epicediów autorstwa Naborowskiego, jak bardzo inspirujące było oddziaływanie na rozwijającą się dynamicznie literaturę narodową w w. XVII formy klasycznego epicedium.

Nieco inaczej przedstawia się obecny stan wiedzy na temat twórczości nagrobkowej. Otrzymaliśmy właśnie niedawno do rąk publikację okazałą, przyciągającą wzrok świetnie wykonaną grafiką obwoluty wg projektu Eugeniusza Geta-Stankiewicza. Jest to ułożona przez wrocławskiego literaturoznawcę Jacka Kolbuszewskiego antologia polskiego epitafium wierszowanego Co mnie dzisiaj, jutro tobie ${ }^{5}$. Autor tej antologii jest najwybitniejszym i najbardziej znanym współczesnym znawcą „literatury cmentarnej”. Jego wcześniejsza książka Wiersze z cmentarza ${ }^{6}$ przyniosła bardzo szerokie omówienie polskiej „kultury śmierci” tzn. obrzędowości oraz jej wyrazów, często bardzo wybitnych, zarówno w literaturze artystycznej, jak też i popularnej. Książka to wyjątkowa i rewelacyjna, bowiem ukazała nam w sposób przekonujący, jak nieoczekiwanie bogate w wiadomości o naszym społeczeństwie i jego tradycji jest właśnie to omijane dotąd przez innych badaczy pogranicze folklorystyki, literaturoznawstwa porównawczego i historii literatury polskiej. Także i wydane w popularnej, acz bardzo starannie opracowywanej serii Cmentarze tegoż autora mogą stanowić solidną zachętę dla pogłębiania wiedzy o polskiej kulturze funeralnej. Natomiast ostatnio opublikowana antologia Jacka Kolbuszewskiego jest dziełem o zamierzeniach wielkokierunkowych. Udostępnia ona w sposób zaledwie cząstkowy, w świadomym i z rozwagą dokonanym wyborze bogate materiały zgromadzone przez autora i dokumentujące dzieje wierszowanego nagrobka polskiego od doby staropolskiej aż po czasy najnowsze. Ta wymuszona cząstkowość właśnie daje pojęcie o rozległości całej problematyki historycznoliterackiej, folklorystycznej, historycznoartystycznej i wreszcie antropologicznofilozoficznej polskiego epitafium.

\footnotetext{
${ }^{5}$ Co mnie dzisiaj, jutro tobie. Polskie uiersze nagrobne. Zebrał, wyboru dokonał, wstępem i objaśnieniami opatrzył J. Kolbuszewski, Wrocław 1996.

${ }^{6} \mathrm{~J}$. Kolbuszewski, Wiersze z cmentarza. O uspótczesnej epigrafice wierszowanej, Wrocław 1985 (Polskie Towarzystwo Ludoznawcze. Biblioteka Popularnonaukowa tom IX. Pod redakcją naukową Leszka Dzięgla).
} 
Konieczność dokonywania wyboru zmuszała autora antologii do podejmowania decyzji trudnych i zawsze dyskusyjnych. Nie jestem więc pewien, czy aby nie wzbudzi wątpliwości u dociekliwego czytelnika wyłączenie z antologii „polskiego wiersza nagrobnego” epitafium lacińskiego. Uświadamiamy wszak sobie lepiej aniżeli kiedykolwiek „polskość” tekstów pisanych przez Polaków po łacinie i nie trzeba już dzisiaj osobno zajmować się dowodzeniem słuszności tego przekonania. Wszak to właśnie łacińska lapidarność wyrazu obowiązująca w epitafium uczyła zwięzłości i pomysłowości twórców polskojęzycznych nagrobków. Ten sam ścisły związek zauważyliśmy już zresztą w przypadku łacińskiego epicedium i jego po polsku pisanych odmian. Autor antologii doskonale zdaje sobie również z tego sprawę, kiedy omawia we wstępie to zagadnienie i uprzedza ewentualne zastrzeżenia stosownymi wyjaśnieniami. Otóż na ewentualną obronę Jacka Kolbuszewskiego przed strezsczonym wyżej zarzutem przytoczyłbym, może paradoksalnie, tę samą rację, którą kierował się kiedyś Szymon Starowolski, gdy układał swoje Monumenta Sarmatarum. Nie umieścił tam, jak wiadomo tekstów pisanych po polsku. Z tego tytułu - o ironio! - czyni zarzut barokowemu polihistorowi zarówno sam Jacek Kolbuszewski jak i przywołany tu w odsyłaczu monografista literackiego epitafium barokowego Janusz Rećko ${ }^{7}$. Otóż w rozdziale wstępnym do antologii Kolbuszewskiego zatytułowanym Literatura, epigrafika i groby czytamy taką uwagę: „Najbardziej jednak w istocie — rzecz jasna rozumiejąc «metodologiczne» racje i autorskie intencje Starowolskiego - ubolewać można nad tym, iż w dziele swym całkowicie pominął on inskrypcje w języku polskim" ${ }^{8}$. Nie sądzę jednak, że uznanie tego faktu także i przez Janusza Rećkę za „istotny mankament” jest, jak pisze Jacek Kolbuszewski „sądem niemal powszechnym”. A czy myśląc kategoriami klasycznymi można by było w ogóle napisać „epitafium” nie po łacinie, lecz po polsku? Tak jak trudno sobie wyobrazić polskojęzyczną elegię, odę czy też nawet wspomniane wcześniej epicedium. Polskojęzyczna parafraza tych gatunków to przecież całkiem coś innego. W przypadku Starowolskiego trzeba by było poza tym owe polskie „epitafia” przekładać na właściwe formalnie epitafia łacińskie... Rozumiem przeto obiekcje Starowolskiego i biorę jego stronę w sporze. Jednak te same racje, do których zgłaszają zastrzeżenia obaj współcześni badacze epitafium, a także polskich wierszów nagrobkowych, przemawiają również w obronie kontrowersyjnej i do samego końca jednak mnie nie przekonującej decyzji edytorskiej Jacka Kolbuszewskiego, aby nie uwzględniać polskiego epitafium łacińskojęzycznego. Mamy tu bowiem do czynienia z wierszami nagrobnymi, które przypominają klasyczne epitafia właściwie tylko krótkimi rozmiarami i wykorzystywaną czasami klasyczną topiką. Ducha łacińskości z takiego „epitafium” wyegzorcyzmowano tu

\footnotetext{
7 J. Rećko, Literackie epitafium barokowe. Geneza i teoria gatunku. Zielona Góra 1992, s. 92. Dodajmy tu, że ta pożyteczna i obfita w rzeczowe informacje monografia nowożytnego epitafium zasługuje na wznowienie w bogatszej edytorsko postaci.

${ }^{8}$ J. Kolbuszewski, Co mnie dzisiaj, jutro tobie, jw., s. 12.
} 
dokumentnie. Zresztą widzimy, że łaciński właśnie prześladowca skrybów, chochlik Titivillus, i tak się zemścił na nie oswojonych z laciną korektorach, którzy na s. 48 dopuścili do druku takie oto „objaśnienie” powszechnie stosowanego starożytnego skrótu D. O. M.: „Deo Omnipotento [!] Magnifico". Szkoda jednak zwracać uwagę na drobiazgi, gdy mamy do czynienia z publikacją bezprecedensową, ukazującą nieznany właściwie dotąd, a już prawie całkowicie zapomniany świat obrazów, dziwnych konstrukcji stylistycnych i przeplatających się w sposób niezwykły składników różnych tradycji estetycznych. Każdy z zamieszczonych w antologii wierszów czy napisów nagrobnych opatrzono równolegle, jakby na marginesie stronicy znakomitymi i koniecznie potrzebnymi wobec takowego „materyi pomieszania” drobiazgowymi objaśnieniami. Są tam materiały do przemyśleń na temat jakże różnych dróg krążenia i wzajemnego na się oddziaływania składników literatury artystycznej polskiej i powszechnej. Swoisty „intertekstualizm”, z którym tu naocznie mamy do czynienia, dokumentuje obieg motywów literackich o zupełnie wyjątkowej dynamice (np. oddziaływanie u nas haiku!) i zarazem przywiązanie do eschatologii chrześcijańskiej. Aż korci zapytać o teksty na nagrobkach innych wyznań. Ale to nic pytanie — raczej prośba do Jacka Kolbuszewskiego skierowana o dalsze tego rodzaju publikacje.

Ta niezmiernie cickawa i pouczająca antologia polskiego nagrobka wierszowanego ma ostatecznie jeszcze jedną zaletę. Skłania czytelnika do tego, aby raz jeszcze powrócił do pytania o bezradność poezji wobec śmierci. Sformułowałbym nawet to pytanie w sposób jeszcze bardziej bezwzględny: czy warto zajmować się twórczością, która na temat śmierci i cierpienia wypowiada się z zasady konwencjonalnie, często naiwnie, czasami z zabawną nonszalancją a niekiedy wręcz irytująco, bo z niezamierzonym w intencji komizmem? Wszak większość spośród wierszowanych nagorbków wyraża się o tych sprawach bez umiaru, zbyt hałaśliwie i zbyt dosłownie. Sądzę, że publikacja Jacka Kolbuszewskiego uświadamia czytelnikowi, który dotąd nie miał czasu się nad tym zastanawiać, iż nagrobek - zarówno ten fizycznie istnicjący pomniczek cmentarny, jak i wierszyk na nim umieszczony — należy do kultury życia, nie do kultury śmierci. Tak jak do życia należą ludowe zwyczaje pogrzebowe, których manifestowana spontanicznie witalność równoważy traumę zgonu.

Andrzej Borowski

\section{Hanna Dziechcińska, \\ Kultura literacka $w$ Polsce XVI i XVII wieku. Zagadnienia wybrane, Warszawa 1994}

Zjawiska składające się na szeroki obraz kultury literackiej epoki staropolskiej od wielu lat przyciągają uwagę badaczy. Kwestie kształtowania się publiczności, funkcjonowania i obiegu dzieł, formowania myśli krytycznoliterackiej tworzą niezmiernie ważny kontekst interpretacyjny dla poszczególnych utworów. Trzeba przyznać, że problemy te są jednocześnie 